\title{
An Assessment of the Spiny Lobster Panulirus homarus Fishery in Oman - Another Decline in the Western Indian Ocean?
}

\author{
A. Al-Marzouqi, A. Al-Nahdi, N. Jayabalan and J.C. Groeneveld \\ Ministry of Agriculture and Fisheries, Marine Science and Fisheries Centre, P.O. Box 467, Muscat 113, \\ Sultanate of Oman
}

\begin{abstract}
Keywords: Lobster, Lobster fisheries, Panulirus homarus, Oman, Arabian Sea, Western Indian Ocean region

Abstract-The scalloped spiny lobster Panulirus homarus supports numerous traditional diving, trap and trammel net fisheries in the Western Indian Ocean. Commercial catches made in 2003 to 2005 in the Arabian Sea region of Oman (a coastline of $\sim 1100 \mathrm{~km}$, comprising Dhofar and Al-Wusta) were sampled for length and sex composition, and female reproductive condition. On average, lobsters caught in Dhofar were larger than in Al-Wusta, and length-based estimates of growth parameters, size at maturity and natural mortality were consistent with fast-growing tropical lobsters. Compared to historical data from Oman dating from the late-1980's (with peak catches of >2000 t/yr) and mid-1990's, recent landings, average lobster size and size at maturity were considerably lower. A length-based cohort analysis suggested that fishing mortality does not impact on lobsters $<60 \mathrm{~mm}$ carapace length, but that it has depleted those $>80 \mathrm{~mm}$. The spawning biomass ratio $\left(\mathrm{B}_{\mathrm{sp}} / \mathrm{B}\right)$ of $<25 \%$ is sensitive to increases in fishing mortality. Existing regulations are not regularly enforced, and the situation in Oman appears to be typical of lobster fisheries in the northwestern Indian Ocean, where few well-founded management plans exist and several declines in catches have been reported.
\end{abstract}

\section{INTRODUCTION}

The scalloped spiny lobster Panulirus homarus is widely distributed in the tropical and subtropical waters of the Indo-West Pacific, where it inhabits shallow (1-90 m) rocky substrates and coral reefs (Holthuis 1991). Three geographically separated forms are recognized based on colour and abdominal sculpturation, namely $P$. homarus homarus from eastern Africa to Japan, Indonesia and Australia, $P$. homarus rubellus from Madagascar and southeastern Africa, and P. homarus megasculptus from the northwestern Indian Ocean, including Somalia and the Arabian Sea (Berry 1974; Holthuis 1991). All three forms may overlap and co-occur with other nearshore Panulirus species, i.e. $P$. ornatus, $P$. versicolor, $P$. longipes and $P$. penicillatus (Holthuis 1991). The tropical and sub-tropical Panulirus species generally grow fast, mature within 2-3 years of settlement to the seafloor, may moult and reproduce several times per year, and carry large numbers of comparatively small eggs (see review by Phillips and MelvilleSmith 2006).

Abundances of tropical spiny lobsters are generally low and few countries in the Indo-West Pacific have high volume fisheries (Munro 2000). Nevertheless, the high product value of spiny lobsters on local and export markets ensures that they are caught wherever they can be found, mainly by traditional (artisanal) fishers using a variety of fishing methods including capture by hand or spearing, tangle nets or traps (Munro 2000; Phillips and Melville-Smith 2006). Accurate data on landings by the traditional fisheries of the region are extremely sparse - catches are 
often not reported, or in other cases landings consist of several species that are grouped (Munro 2000, FAO 2005). Nevertheless, the information available does suggest a decline of the total lobster landings of the western Indian Ocean (FAO Area 51; van der Elst et al. 2005), and several alarming declines from country statistics in the northwestern Indian Ocean. Landings from Indian fisheries for tropical Panulirus lobsters (several species, incl. $P$. homarus) have declined sharply since 1985 peak catches (Radhakrishnan et al. 2005) and in Yemen catches of $P$. homarus are also at a fraction of earlier levels (approx. $300 \mathrm{t} / \mathrm{yr}$ compared to $>1200 \mathrm{t}$ in the early 1990s; Anon 2004). Catches in

Somalia appear to have declined significantly since the 1990s (Fielding and Mann 1999), and Mohan (1997) showed a decline in the size composition of catches made along the Dhofar coast of Oman.

The fishery for Panulirus homarus in the Sultanate of Oman originated from incidental catches made around Masirah Island in the early 1970's, and expanded in the 1980's to the Arabian Sea coast between Masirah in the north and Dalkut in the south $\left(16\right.$ to $21^{\circ} \mathrm{N}$; see Fig. 1). Fishers use traps and tangle-nets from small motorized fibreglass boats, and catch predominantly $P$. homarus, with negligible amounts of other lobster species. Reported landings have declined from over

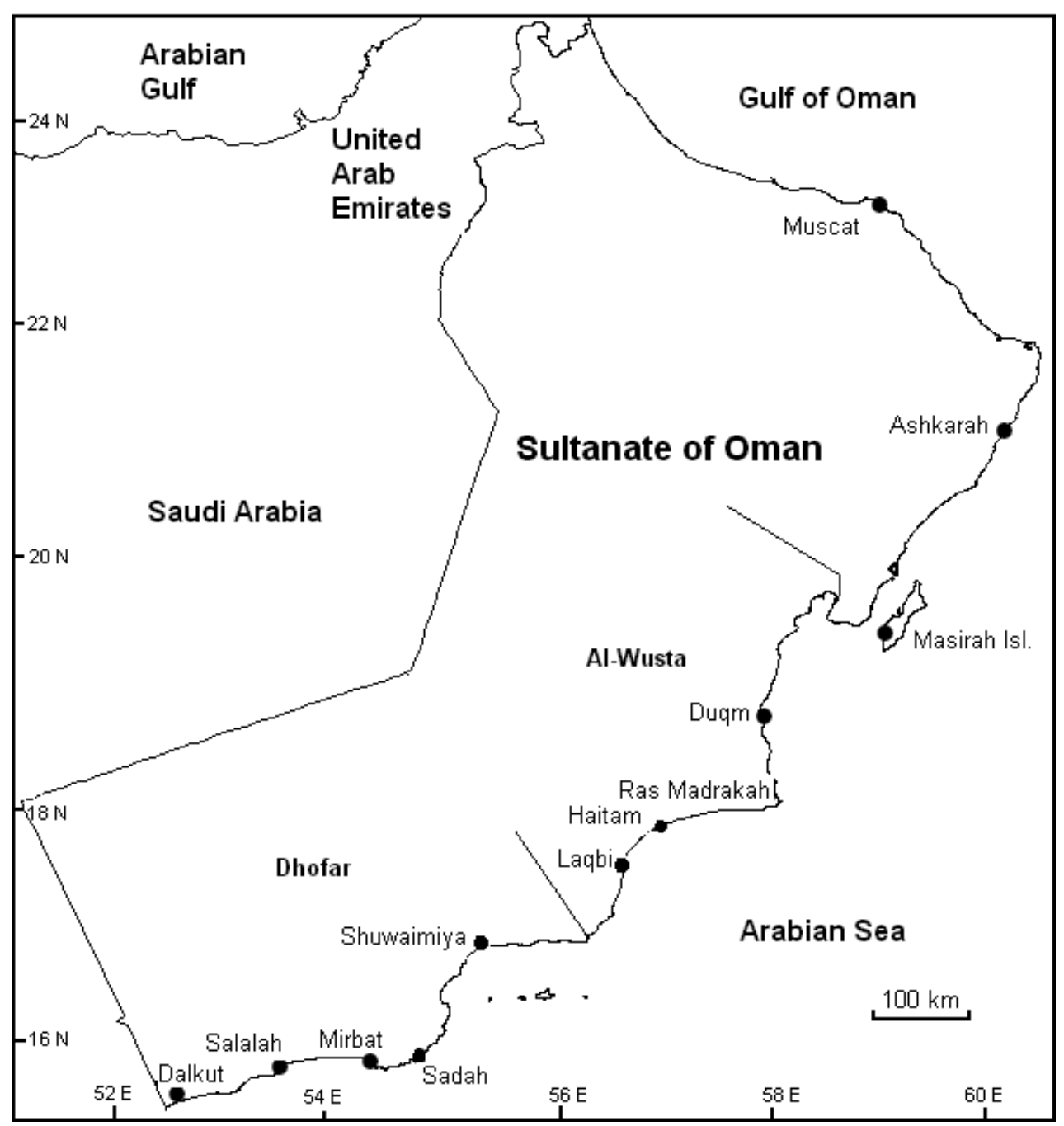

Fig. 1. The Arabian Sea coast of Oman showing the Dhofar and Al-Wusta regions and the locations of the lobster landing sites covered in this study
$2000 \mathrm{t} / \mathrm{yr}$ in the 1980 's to between 200 and $500 \mathrm{t} / \mathrm{yr}$ after the turn of the century (Fig. 2; Anon 2001, 2006). Catches are exported to Dubai (United Arab Emirates) and other international markets to earn foreign exchange of approximately \$US 3-5 million per year. Present regulations include a 2-month fishing season $\left(15^{\text {th }}\right.$ October $-15^{\text {th }}$ December $)$, minimum legal size (MLS) of $80 \mathrm{~mm}$ carapace length $(\mathrm{CL})$, and bans on using nets or retaining eggbearing females, but they are not regularly enforced. The biological and population parameters needed to determine plausible management strategies are either unknown, or based on limited research done more than a decade ago (Al-Abdulsalaam 1989; Johnson 1990; Johnson and Al-Abdulsalaam 1991; Mohan 1997).

The objectives of this study were to asses the present status of the spiny lobster stock and fishery relative to historical information from Oman, and to compare the local situation with similar lobster fisheries in the northwestern Indian Ocean. Length-based data were used to assess spatio-temporal trends in size composition and size at sexual maturity, estimate growth and mortality rates, and assess the impact of fishing on populatio biomass and yields in Oman. The results of this

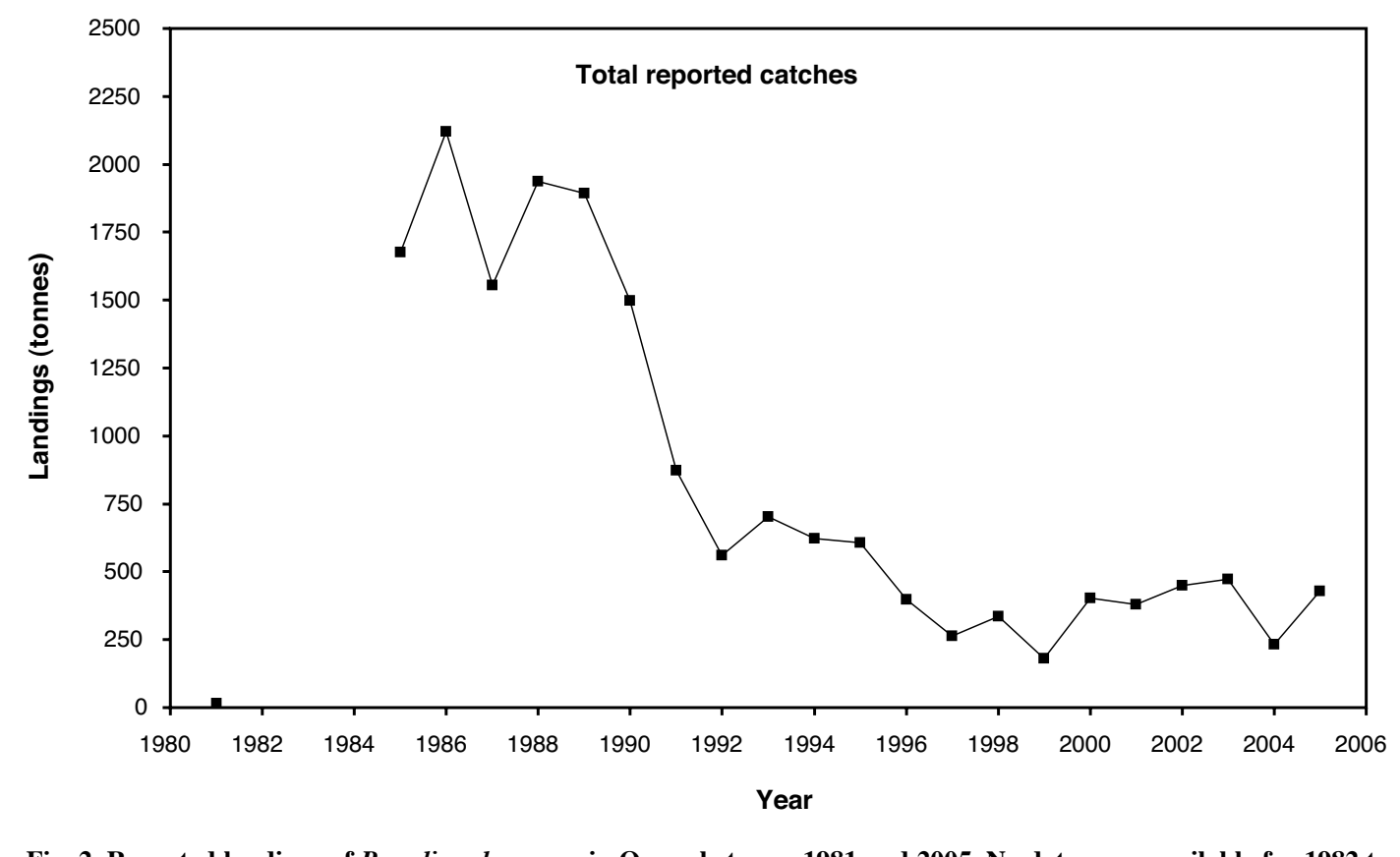

Fig. 2. Reported landings of Panulirus homarus in Oman between 1981 and 2005. No data were available for 1982 to

1984. Records were obtained from Al-Barwani et al. (1989) and Statistics Yearbooks (Anon 2001 \& 2006)

study are intended as a benchmark against which the success of future management strategies can be measured.

\section{MATERIAL AND METHODS}

Sampling strategy and analysis of size composition and length-mass data

Lobsters landed by commercial fishers during the October to December fishing seasons of 2003 to 2005 were sampled at landing sites in Al-Wusta (Duqm, Ras-Madrakah, Haitam, Laqbi) and in Dhofar (Shuwaimiya, Sadah, Mirbat, Salalah, Raysut, Mughsyl, Dalkut) (see Fig. 1). Sampling frequencies / site were irregular, and additional catches confiscated during January to October were sampled whenever available. All lobsters landed at a site on a given sampling day were sexed, and measured mid-dorsally from the transverse ridge between the frontal spines to the posterior carapace edge $(C L \pm 0.1 \mathrm{~mm})$ using a vernier calliper. Student's two-sample t-tests or ANOVA were used to identify differences in CL between years (2003, 2004 and 2005), regions (Al-Wusta, 
Dhofar) and sexes ( $\alpha=0.05$; Zar, 1984). A subsample of 157 undamaged specimens covering a size range of 37.7-100.6 mm CL were weighed (Whole Mass; $\mathrm{WM} \pm 1 \mathrm{~g}$ ) for calculation of lengthmass relationships.

\section{Size at maturity}

Female lobsters were categorized as being immature (no ovigerous setae present), mature with a tar-spot attached but no egg-mass, and mature with an eggmass attached to the abdomen. Two methods were used to estimate size-at-50\% maturity - the ratios of females with ovigerous setae to the total number of females per 2-mm CL interval ('setal' method), and the ratios of egg-bearing (or berried) females to the total number per 2-mm CL interval ('berry' method) (see Groeneveld and Melville-Smith 1994). In both methods females with a tar-spot were assumed to be mature. For the berry method only females collected during the October to December main breeding season were used and the proportions of egg-bearing females per 2-mm interval were adjusted to range between zero and $1\left(\mathrm{p}_{\mathrm{i}} / \mathrm{p}_{\max } \times\right.$ $n_{i}$ where $p_{i}$ is the proportion of egg-bearers in the $\mathrm{i}^{\text {th }}$ interval and $\mathrm{p}_{\max }$ is the interval with the highest egg-bearing proportion). A logistic curve:

$\mathrm{f}_{\mathrm{m}}=1 /[1+\exp (\mathrm{a}-\mathrm{b} \times \mathrm{CL})]$,

was fitted in each case, where $f_{m}$ is the frequency of mature females and $\mathrm{a}$ and $\mathrm{b}$ are constants obtained by a non-linear search algorithm (using a least squares fitting procedure) provided by an Excel software package (Microsoft 1997). The CL-at-50\% maturity $\left(\mathrm{L}_{50}\right)$ was determined by back calculation.

\section{Growth}

The von Bertalanffy growth parameters $\mathrm{K}\left(\mathrm{y}^{-1}\right), \mathrm{L}_{\infty}$ $(\mathrm{mm})$ and $\mathrm{t}_{0}(\mathrm{yr})$ were estimated from the lengthfrequency data using the Fisheries Managemen Science Programme (FMSP) Fish Stock Assessmen software (LFDA, Windows-based version 5.0; MRAG, UK). Two sets of length frequency data were used: a pooled year-wise dataset analysed by the Shepherd's Length Composition Analysi (SLCA) for each year separately; and disaggregated length-frequency data for specific sampling episodes over the 2003 to 2005 period. In the latter analysis, three alternative fitting methods, SLCA, PROJMAT and ELEFAN 1 (Pauly 1987) were used to estimate the parameters. In both cases, a nonseasonal growth curve was selected.

\section{Mortality estimates}

The instantaneous total mortality $(Z)$ was estimated from three equilibrium length-based approaches, using the same underlying model but differing in the way parameters are estimated (methods described in Sparre and Venema 1998), i.e.: linearized length-converted catch curves (Pauly 1983; 1984a; 1984b), after using the inverse von Bertalanffy growth equation to convert length data into age; the Beverton and Holt (1956) equation relying on the functional relationship between $\mathrm{Z}$ and the mean lengths of lobsters under full exploitation; and the modified Wetherall et al. (1987) method, which also gave additional estimates of $\mathrm{L}_{\infty}$. All these methods are standard and equations are therefore not shown. Estimates were obtained for each of the three years separately and for all data combined. It is assumed that the frequency distributions of our samples reflect the behaviour of cohorts, that recruitment and mortality rates are constant, and that the population is stable.

Empirical methods used to estimate natural mortality (M) were its relationships with $\mathrm{K}, \mathrm{L}_{\mathrm{m}}$ and $\mathrm{L}_{\infty}$ (Beverton and Holt 1959), longevity (Alagaraja 1984), and age at maturity (Rikhter and Evanov 1976), all shown in Sparre and Venema (1998). The intantaneous fishing mortality rate $(\mathrm{F})$ was computed as $\mathrm{F}=\mathrm{Z}-\mathrm{M}$, and the exploitation rate $(\mathrm{E})$, as $\mathrm{E}=\mathrm{F} / \mathrm{Z}$.

\section{Yield and biomass}

Jones' length-based cohort analysis (Jones and Van Zalinge 1981) was used to estimate F-at-length after raising the pooled length-composition samples to the average annual catch taken over the 2003 to 2005 period ( $378 \mathrm{t} / \mathrm{yr})$, using the length-weight regression for both sexes combined. A length-based Thompson and Bell model, with inputs F-at-length arrays, constant recruitment to the smallest lengthgroup (20-25 mm CL), a range of natural mortality estimates $\left(0.59-0.89 \mathrm{y}^{-1}\right)$ and the parameters of the length-mass relationship was used to predict survivors per length(age)-class (Nt), equilibrium biomass and yield for a range of fishing mortality (F)-factors between 0 (unfished) and 4 (4 times present fishing mortality). Spawning biomass (B or mature females capable of bearing eggs) was calculated as a proportion of the biomass per length category $\left(0.5 \times B_{70-120 \mathrm{~mm}}+0.25 \times B_{65 \mathrm{~mm}}+0.125 \times B_{60 \mathrm{~m}}\right.$ , assuming that $50 \%$ of the biomass/length class between $70-120 \mathrm{~mm} \mathrm{CL}\left(B_{70-120 \mathrm{~mm}}\right)$ will be females, that $50 \%$ of females of $65-70 \mathrm{~mm}$ CL will be mature $\left(B_{65 \mathrm{~mm}}\right)$, and that $25 \%$ of females of $60-65 \mathrm{~mm}$ $\left(B_{60 \mathrm{~mm} m}\right)$ will be mature; see results of size at maturity analysis below. Based on an average annual catch of $378 \mathrm{t} / \mathrm{yr}$ as Yield $(\mathrm{Y})$, the MSY was calculated using Gulland's (1965) formula of MSY $=0.5 \times \mathrm{Z}(\mathrm{Y} / \mathrm{F})$ To assess the influence of unreported catch on the biomass estimate, the model was re-run assuming that the un-reported catch was equal to the reported catch (i.e. a total catch of $756 \mathrm{t}$ per year)

\section{RESULTS}

Size- and sex composition, size at maturity and length-mass relationships

Of the 15,773 lobsters sampled over the three year of the project, $77 \%$ were captured in the Dhofa region, and the remainder originated from $\mathrm{Al}$-Wusta, where a large percentage of samples (52\% in 2004 and all of 2005) consisted of lobsters confiscated from fishers outside of the October-December fishing season (Table 1). The majority of lobsters sampled from legitimate and confiscated catches were smaller than the MLS of $80 \mathrm{~mm} \mathrm{CL}$ in both regions and all three years (Table 1; Fig. 3).

The mean lobster size of catches made along the Arabian Sea coast was $75.4 \pm 10.9$ [S.D.] mm CL (range, 22.6-127.4 mm), and lobsters from Dhofar were significantly larger than those from Al-Wusta (77.0 $\pm 9.9 \mathrm{~mm}$ versus $69.8 \pm 12.5 \mathrm{~mm}$; $\mathrm{t}=31.72, \mathrm{p}<0.001)$ (Table 1). Males were larger than females in Dhofar (78.2 $\pm 9.9 \mathrm{~mm}$ versus $75.9 \pm 9.7$ $\mathrm{mm} ; \mathrm{t}=13.24, \mathrm{p}<0.001)$ but smaller than females in Al-Wusta $(67.9 \pm 12.9$ versus $71.8 \pm 11.7 \mathrm{~mm}$; $t=9.46, p<0.001)$. No decline in size composition was obvious over the three years in Dhofar, but in Al-Wusta both male- and female size declined sharply after 2003 (ANOVA: $\mathrm{F}_{2,1802}=135.8, \mathrm{p}<0.001$ for males and $\mathrm{F}_{2,1768}=127.3, \mathrm{p}<0.001$ for females; Fig. 3).

The pooled sex ratio for both regions and all three years combined was close to parity $(0.49: 0.51)$, and the proportions of males and females were also equal in pooled samples from Al-Wusta (0.5:0.5) and Dhofar (0.49:0.51), respectively. However, males were in a distinct minority $(0.31: 0.69)$ in $\mathrm{Al}$ Wusta in 2003, for which a relatively small sample size of only 675 lobsters was available (Table 1).

Table 1. "The numbers of Panulirus homarus sampled in Al-Wusta and Dhofar in 2003 - 2005, showing the minimum, maxim and mean sizes (CL, mm), sex ratios, proporton os samples fro outside the October - December fishing season, and the proportion of samples with a $C L<80 \mathrm{~mm}$ MLS"

\begin{tabular}{|c|c|c|c|c|c|c|c|c|c|}
\hline Area & Year & $\mathbf{n}$ & $\underset{(\mathbf{m m})}{\mathbf{C L}(\min )}$ & $\underset{(\mathrm{mm})}{\mathrm{CL}(\max )}$ & $\begin{array}{c}\text { CL(avg) } \\
(\mathbf{m m})\end{array}$ & $\begin{array}{l}\text { S.D. } \\
\text { (mm) }\end{array}$ & $\begin{array}{l}\text { Sex ratio } \\
(\mathbf{M}: \mathbf{F})\end{array}$ & $\begin{array}{l}\text { Confisc. } \\
\text { (Prop.) }\end{array}$ & $\begin{array}{c}\text { CL }<\text { MLS } \\
\text { (Prop.) }\end{array}$ \\
\hline \multicolumn{10}{|c|}{ Al-Wusta } \\
\hline & 2003 & 675 & 50.2 & 116.6 & 79.3 & 8.6 & $0.31: 0.69$ & 0.05 & 0.54 \\
\hline & 2004 & 1958 & 22.6 & 102.9 & 67.4 & 13.2 & $0.53: 0.47$ & 0.46 & 0.78 \\
\hline & 2005 & 939 & 40.0 & 102.6 & 68.0 & 9.9 & $0.59: 0.41$ & 1.00 & 0.89 \\
\hline & All & 3572 & 22.6 & 116.6 & 69.8 & 12.5 & $0.50: 0.50$ & 0.52 & 0.76 \\
\hline \multicolumn{10}{|l|}{ Dhofar } \\
\hline & 2003 & 2675 & 30.2 & 118.8 & 77.4 & 8.2 & $0.44: 0.56$ & 0.00 & 0.68 \\
\hline & 2004 & 3777 & 33.6 & 127.7 & 78.2 & 11.0 & $0.47: 0.53$ & 0.02 & 0.57 \\
\hline & 2005 & 5749 & 28.8 & 123.4 & 76.1 & 9.7 & $0.53: 0.47$ & 0.14 & 0.70 \\
\hline & All & 12201 & 28.8 & 127.7 & 77.0 & 9.9 & $0.49: 0.51$ & 0.07 & 0.65 \\
\hline All data & 2003-2005 & 15773 & 22.6 & 127.7 & 75.4 & 10.9 & $0.49: 0.51$ & 0.17 & 0.68 \\
\hline
\end{tabular}



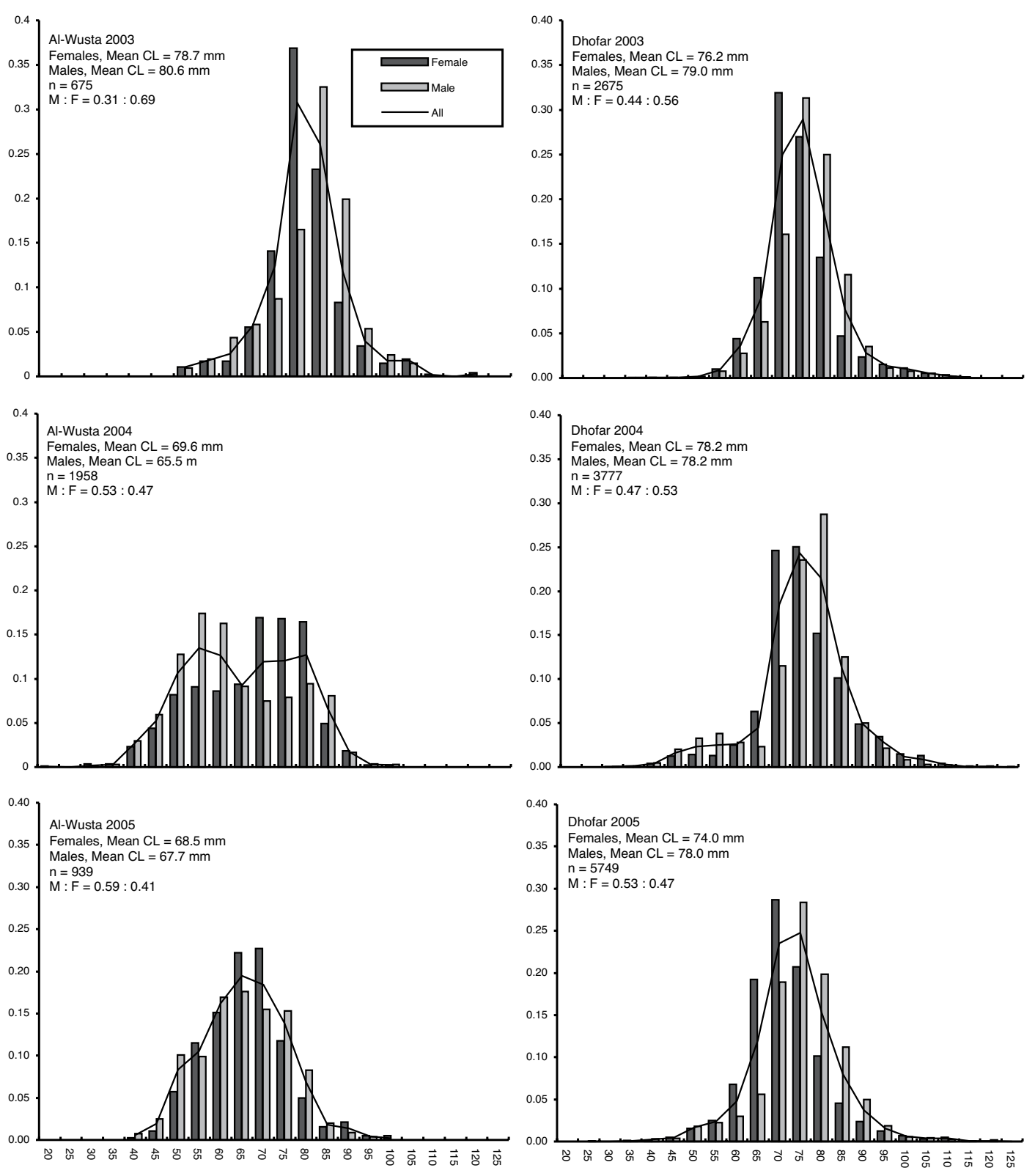

Carapace length $(\mathrm{mm})$

Carapace length $(\mathrm{mm})$

Fig. 3. Length composition (CL in mm) of Panulirus homarus sampled in 2003 to 2005 in the Dhofar and Al-Wusta

The smallest female with a tarspot (which implies that it had mated) was $52.8 \mathrm{~mm} \mathrm{CL}$ and the smallest egg-bearing female was $54.6 \mathrm{~mm}$. Estimates from the logistic curves suggested that $50 \%$ of females reached physiological maturity (ovigerous setae present and mating can occur) at $59.4 \mathrm{~mm} \mathrm{CL}$ and that functional maturity (females able to bear eggs) occurs at $65.7 \mathrm{~mm}$ (Fig. 4)
Functional maturity was reached at similar sizes in Dhofar $(65.6 \mathrm{~mm})$ and Al-Wusta $(63.9 \mathrm{~mm})$ (Fig. 4).

The length-mass relationships fitted to the data were non-linear (Fig. 5) and consequently data were log-transformed prior to testing for significant differences between sexes. Females became progressively heavier than males with increasing
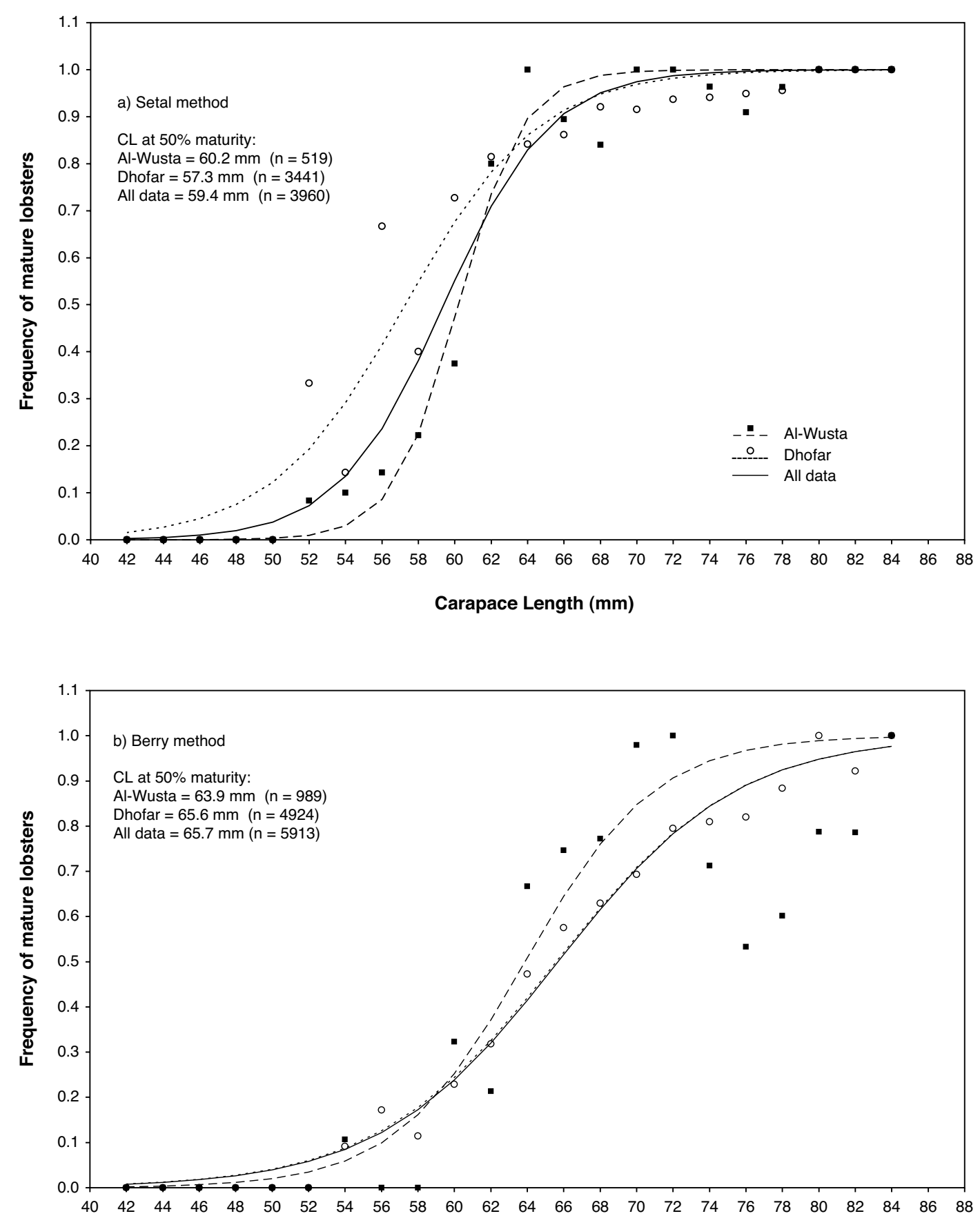

Carapace Length $(\mathrm{mm})$

Fig. 4. Size at 50\% maturity of female Panulirus homarus collected from Dhofar and Al-Wusta, estimated from (a) the presence of ovigerous setae (including individuals with a tarspot present) and (b) the proportions of females with external eggs and / or a tarspot 


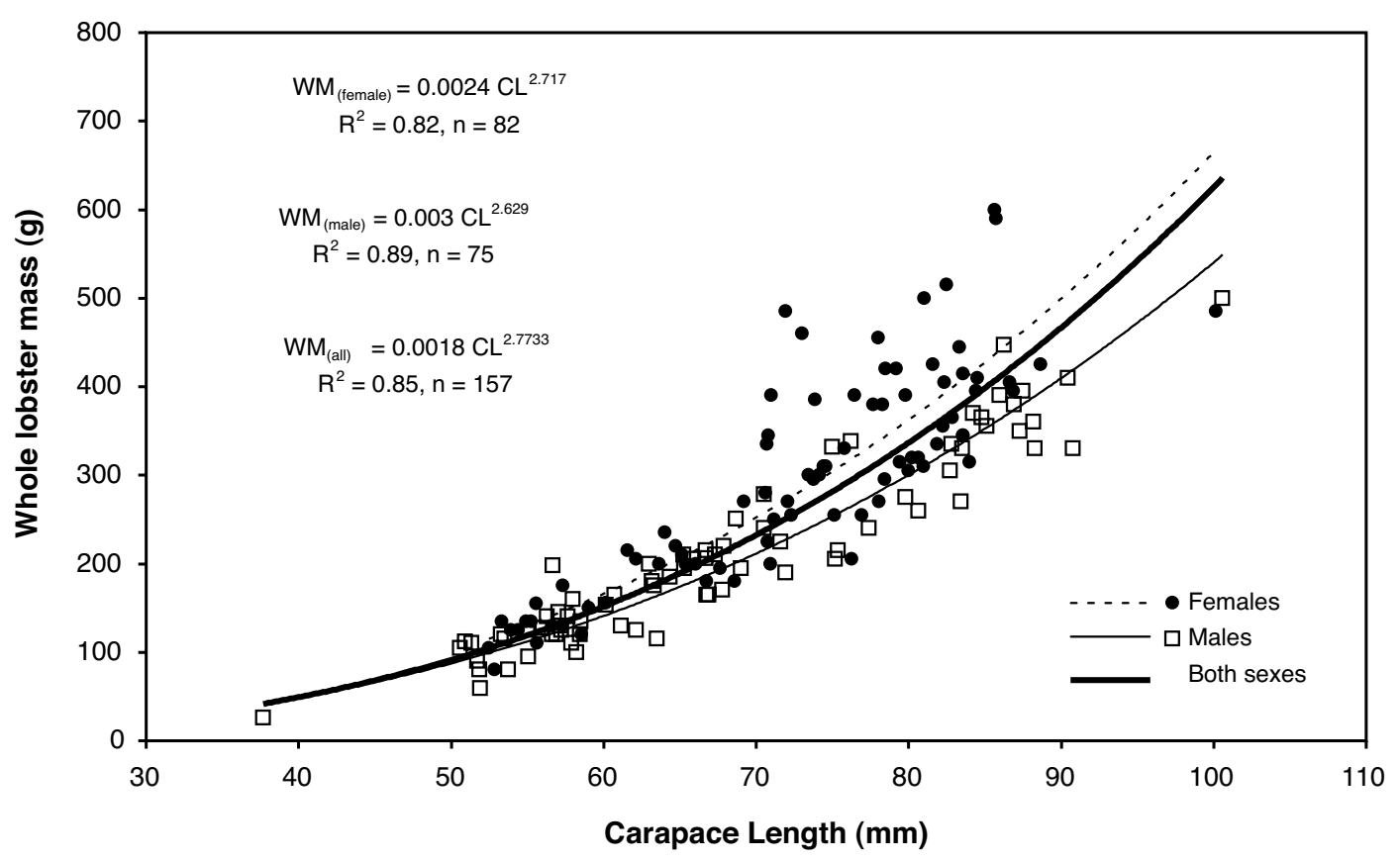

Fig. 5. Length-mass relationships of Panulirus homarus males, females and sexes combined

CL $(\mathrm{t}=0.49, \mathrm{df}=153, \mathrm{p}>0.05$ for slopes; $\mathrm{t}=5.41$, $\mathrm{p}<0.001$ for elevations)

\section{Growth}

The Von Bertalanffy growth parameters estimated for both sexes combined from the length frequency data, ranged from between 126.8 and $136 \mathrm{~mm}$ for $\mathrm{L}_{\infty}, 0.28$ and $0.50 \mathrm{y}^{-1}$ for $\mathrm{K}$, and -0.3 to $-0.9 \mathrm{y}$ for $t_{0}$ (Table 2). The $L_{\infty}$ values are realistic when compared to the maximum observed CL of 127.4 $\mathrm{mm}$, and were further confirmed by an independent estimate of $128 \mathrm{~mm}$ for pooled data using the Wetherall et al. (1987) method. Mean growth parameter estimates were $128.9 \mathrm{~mm}$ for $\mathrm{L}_{\infty}, 0.33$ $\mathrm{y}^{-1}$ and $-0.35 \mathrm{y}$ after omitting the outlier values (Table 2).

Table 2. Summary of Von Bertalanffy growth parameters estimated with Shepherd's Length Composition Analysis (SLCA), and the PROJMAT and ELEFAN 1 software (FMSP stock assessment software, MRAG). The outliers and Wetherall estimate (marked with *) were not included in the average parameter values

\begin{tabular}{llccc}
\hline Method & Year & $\begin{array}{c}\text { L } \infty \\
(\mathbf{m m})\end{array}$ & $\begin{array}{c}\mathbf{K} \\
\mathbf{y r}-\mathbf{1}\end{array}$ & $\begin{array}{c}\mathbf{t 0} \\
\mathbf{y r}\end{array}$ \\
\hline SLCA & 2003 & 131.0 & 0.28 & -0.43 \\
SLCA & 2004 & 126.8 & $* 0.59$ & $*-0.90$ \\
SLCA & 2005 & 129.5 & 0.25 & -0.30 \\
SLCA & $2003-2005$ & 130.0 & 0.40 & -0.41 \\
PROJMAT & $2003-2005$ & 127.0 & 0.31 & -0.31 \\
ELEFAN 1 & $2003-2005$ & $* 136.0$ & 0.41 & -0.30 \\
Wetherall et al. (1987) method & $2003-2005$ & $* 128.0$ & - & - \\
Average parameter values & $2003-2005$ & 128.9 & 0.33 & -0.35 \\
\hline
\end{tabular}

\section{Mortality rates}

The length-converted catch curve based on all data suggested that lobsters younger than 4 years had a relatively higher total mortality $\left(\mathrm{Z}=2.07 \mathrm{y}^{-1}\right)$ than older lobster $\left(1.20 \mathrm{y}^{-1}\right)$, and that the average mortality (Z $\pm 95 \%$ confidence interval $[\mathrm{CI}]$ ) over the fully exploited length range was $1.48 \pm 0.66 \mathrm{y}^{-1}$ $(\mathrm{n}=9$ for regression with lowest $\mathrm{CI})$. The underlying assumption of the catch curve, that $\mathrm{Z} \Delta \mathrm{t}<1$, was not valid for all points, and the approximation is therefore a crude one. The Beverton and Holt (1956) and Wetherall et al. (1987) estimates of Z were slightly higher than those from the lengthconverted catch curve, but with a single exception $\left(2.91 \mathrm{y}^{-1}, 2005\right)$ fell within the $95 \%$ confidence limits of the catch curve values (Table 3). Excluding this outlier, an average value of $\mathrm{Z}$ was estimated to be $1.86 \mathrm{y}^{-1}$.

Length-based cohort analysis and predictive Thompson and Bell model

Fishing mortality (F)-at-length arrays, obtained from the length-based cohort analysis, showed a low impact of fishing on length-classes $<60 \mathrm{~mm}$ $\mathrm{CL}$, and highest impact on those between 70 and $90 \mathrm{~mm} \mathrm{CL}$, irrespective of the value of M selected between 0.59 and $0.89 \mathrm{y}^{-1}$ (Fig. 6). Consequently, the F-array resulting from an average $\mathrm{M}=0.74 \mathrm{y}^{-1}$ was selected as the reference input for the predictive length-based model.

Equilibrium predictions of survivors per lengthclass and yield for a range of fishing strategies (expressed as the fishing mortality factor with F-factor $=1$ indicating the present strategy) suggest that survival of lobsters $<50 \mathrm{~mm}$ CL will remain unaffected by fishing, and that the threshold

Table 3. Summary of total mortality estimates $(Z \pm 95 \%$ conf. int; per year $)$

\begin{tabular}{lllll}
\hline Method & $\mathbf{2 0 0 3}$ & $\mathbf{2 0 0 4}$ & $\mathbf{2 0 0 5}$ & Combined \\
\hline Catch curve & $1.63(0.97)$ & $1.54(0.59)$ & $1.81(0.57)$ & $1.48(0.66)$ \\
Beverton and Holt & 2.08 & 1.76 & 1.99 & 1.92 \\
Wetherall et al. (1987) & 1.91 & 2.1 & $2.9^{*}$ & 2.21 \\
Average parameter estimate & & & & 1.86 \\
\hline
\end{tabular}

* Not used to calculate average value

Beverton and Holt (1959) found that values of the $\mathrm{M} / \mathrm{K}$ ratio generally lie between 1.5 and 2.5 ; thus, assuming a $\mathrm{K}$ of $0.28-0.5 \mathrm{y}^{-1}$ for $P$. homarus, $\mathrm{M}$ values range from $0.42-1.25 \mathrm{y}^{-1}$. Estimates of $\mathrm{M}$ from empirical methods were $1.90-2.12 \mathrm{y}^{-1}$ (Beverton and Holt method with a CL interval of 63-70 $\mathrm{mm}$ at 50\% maturity), 0.76-0.89 $\mathrm{y}^{-1}$ (Richter Evanov formula with an age interval of 1.7-2.0 years at 50\% maturity), and $0.59-0.84 \mathrm{y}^{-1}$ (longevity method with a $1 \%$ survival rate after 5.5 years $[C L=110 \mathrm{~mm}]$ or after 7.7 years $[120 \mathrm{~mm}])$. When excluding the elevated Beverton and Holt estimate, the range for $M$ was $0.59-0.89 \mathrm{y}^{-1}$. Using average values of $\mathrm{Z}\left(1.86 \mathrm{y}^{-1}\right)$ and $\mathrm{M}\left(0.59-0.89 \mathrm{y}^{-1}\right)$, the fishing mortality $(\mathrm{F}=\mathrm{Z}-\mathrm{M})$ lies between 0.97 and $1.27 \mathrm{y}^{-1}$, and the exploitation rate $(\mathrm{E}=\mathrm{F} / \mathrm{Z})$ is at 0.52 to 0.68 length, where fishing at any F-factor $>0$ will affect survival, is $50-60 \mathrm{~mm}$ CL (Fig. 7). Increasing $\mathrm{F}$ above the present level will drastically reduce survival above $70 \mathrm{~mm}$ CL (Fig. 7b). Biomass projections (Fig. 7c) suggest that the total biomass in an unexploited population (F-factor $=0$ ) would be $\sim 1940 \mathrm{t}$, comprising individuals in a wide size range of $60-115 \mathrm{~mm} \mathrm{CL}$. At the present level of fishing mortality (F-factor=1) the biomass projection is reduced to $\sim 1050 \mathrm{t}$, with most of the biomass concentrated in the $50-80 \mathrm{~mm}$ CL range. Assuming an unreported catch of $378 \mathrm{t}$ in addition to the reported catch per year (i.e., total catch $=$ $756 \mathrm{t}$ ), increases the present biomass estimate from $1050 \mathrm{t}$ to $2094 \mathrm{t}$. F-factors $>1$ will further reduce the biomass contained in length-classes $>70 \mathrm{~mm} \mathrm{CL}$. Spawning biomass as a proportion of biomass $\left(\mathrm{B}_{\mathrm{sp}}{ }^{\prime}\right.$ B) at F-factor $=1$ is expected to be $\sim 25 \%$ of pristine, 


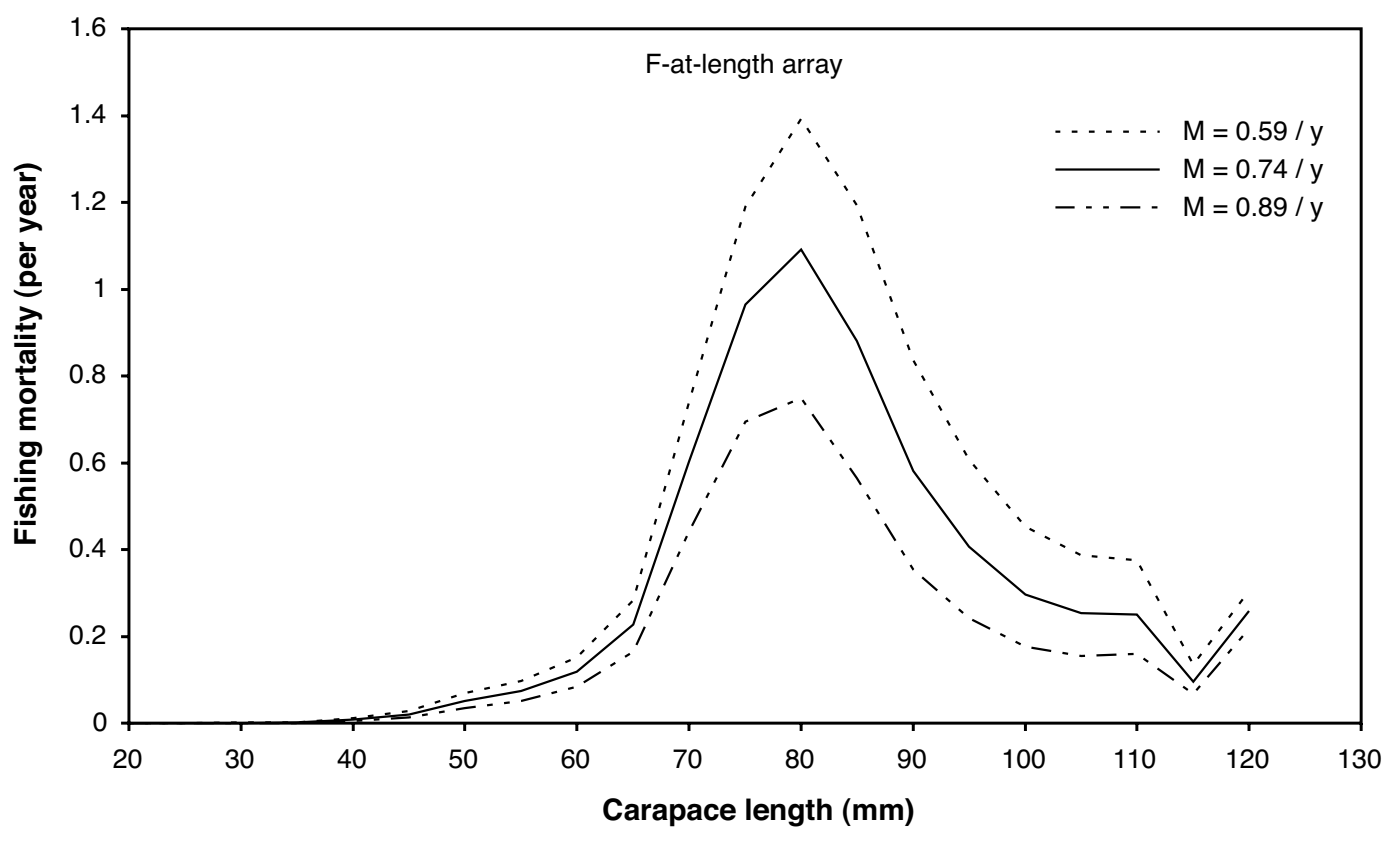

Fig. 6. F-array (fishing-mortality-at-length) estimated from all samples combined for a range of natural mortality (M) estimates $\left(0.59-0.89 \mathrm{y}^{-1}\right)$

but any increase above F-factor=1.5 will reduce this ratio to $<18 \%$ (Fig. 8). The yield curve is relatively insensitive to changes in effort above F-factor=1, however Gulland's (1965) method suggested an effort reduction of about $27 \%$ to achieve an MSY of $276.8 \mathrm{t}$ per year.

It is important to remember, however, that the equilibrium conditions assumed for the model (i.e. constant recruitment, growth and mortality) are rarely achieved in reality, where environmental and fisheries forces are not constant. The limitations of the model, and particularly the potentia consequences of increased fishing pressure on smaller size classes (theoretically insignificant based on the model; see above) should therefore be viewed with caution.

\section{DISCUSSION}

A first glance at the catch history of $P$. homarus in Oman between 1981 and 2005 suggests an exploitation pattern that is fairly commonly observed in lobster fisheries world-wide, i.e. the commercial discovery of a new resource and rapidly increasing catches to far above sustainable levels (1981-1989 in Oman), a steep decline (here 1990-
1995), and then a more stable period at a fraction of the peak catches. The latter phase usually follows on management interventions to curb fishing effort, and a local lengthy 10-month closed season each year appears to have succeeded, at least partially, in stabilizing catches. Nevertheless, the average annual catch for the 1999-2005 period remains at $\sim 20 \%$ of that reported for the late 1980s (see Fig. 2). No decline in the average size of lobsters caught off Dhofar was apparent for the 2003-2005 period, at a reduced abundance level. Such a temporal equilibrium over the sampling period is one of the main assumptions of the length-based methods used in this study (Hilborn and Walters 1992).

Data were pooled from numerous landing sites in Dhofar and Al-Wusta to obtain an overall perspective of the fisheries in these two regions. This may have introduced some bias because of high variability in population size structure between sites (Johnson and Al-Abdulsalaam 1991; Mohan 1997), but was necessitated by incomplete coverage of sites in each year between 2003 and 2005. It is important to note that the MLS of $80 \mathrm{~mm} \mathrm{CL}$ is not observed in the fishery, and that size selectivity by fishers (but not by gear) could therefore be thus providing some support for an equilibrium
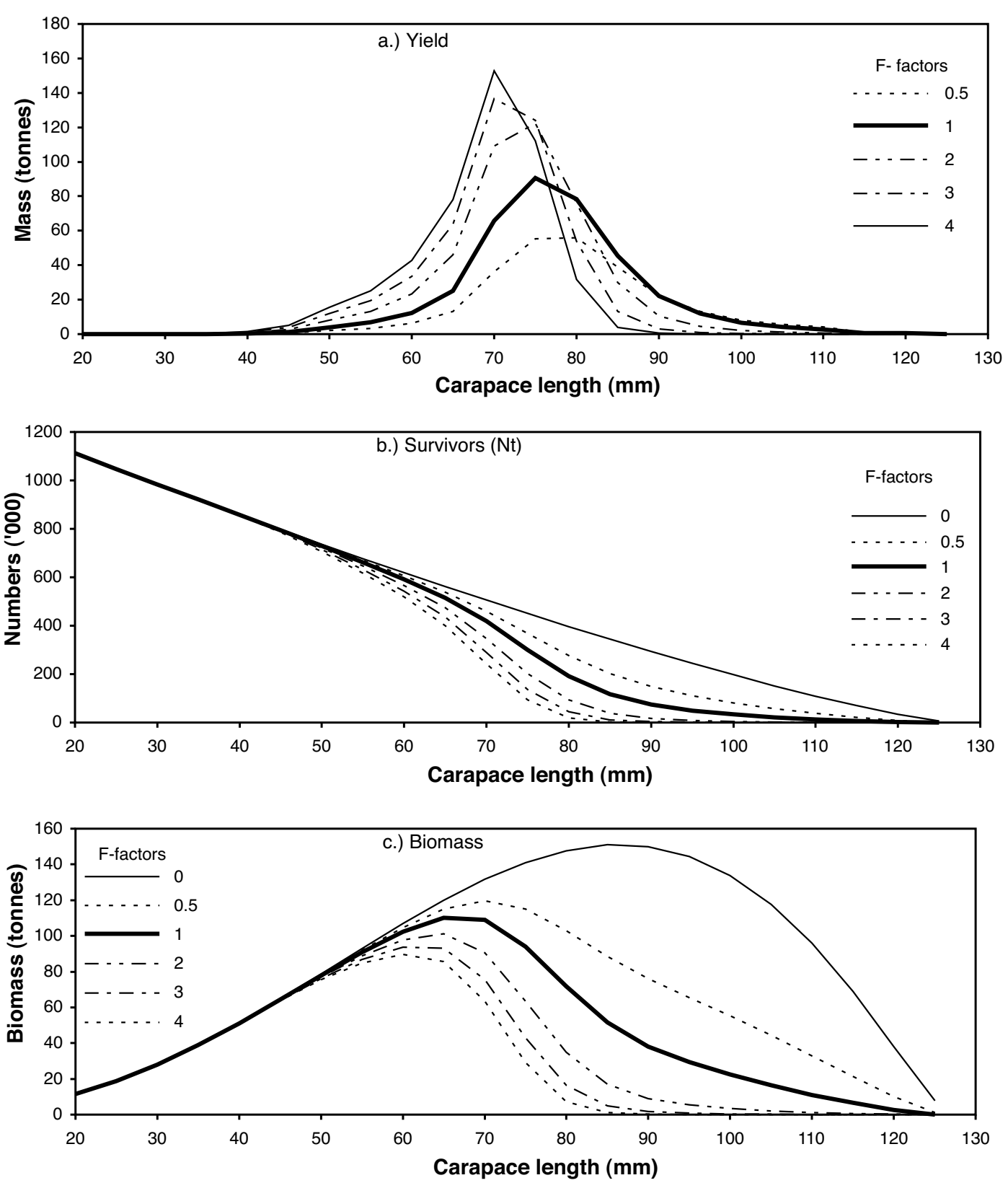

Fig. 7. Projections of yield (tonnes), survival ( $\mathrm{Nt}$ ) and biomass per length-class for a range of fishing strategies Fig. 7. Projections of yield (tonnes), survival (Nt) and biomass per length-class for a range of fishing strategies
$(0<$ F-factor $<4$; where 0 denotes no fishing, 1 is the present fishing mortality, and 4 is four times the present fishing mortality)

discounted. The mean CL in Dhofar (77.0 \pm 9.9 $\mathrm{mm}$ ) was $\sim 3 \mathrm{~mm}$ smaller than at the height of the fishery in 1987-1988 (79.9 mm CL, $\mathrm{n}=4519$; data recalculated from Al-Abdulsalaam 1989), and than in 1994-1995 (80.2 mm CL, $\mathrm{n}=1072$; Mohan 1997). The relatively small reduction in mean size of captured lobsters since the late 1980s in Dhofa is somewhat surprising, given the large decrease in catches between these two periods, although there may have been substantial reductions in size prior to 1989 (Johnson and Al-Abdulsalaam 1991; Mohan 1997).

A much sharper decline in mean lobster size was observed in Al-Wusta, from $87.6 \mathrm{~mm} \mathrm{CL}$ in 


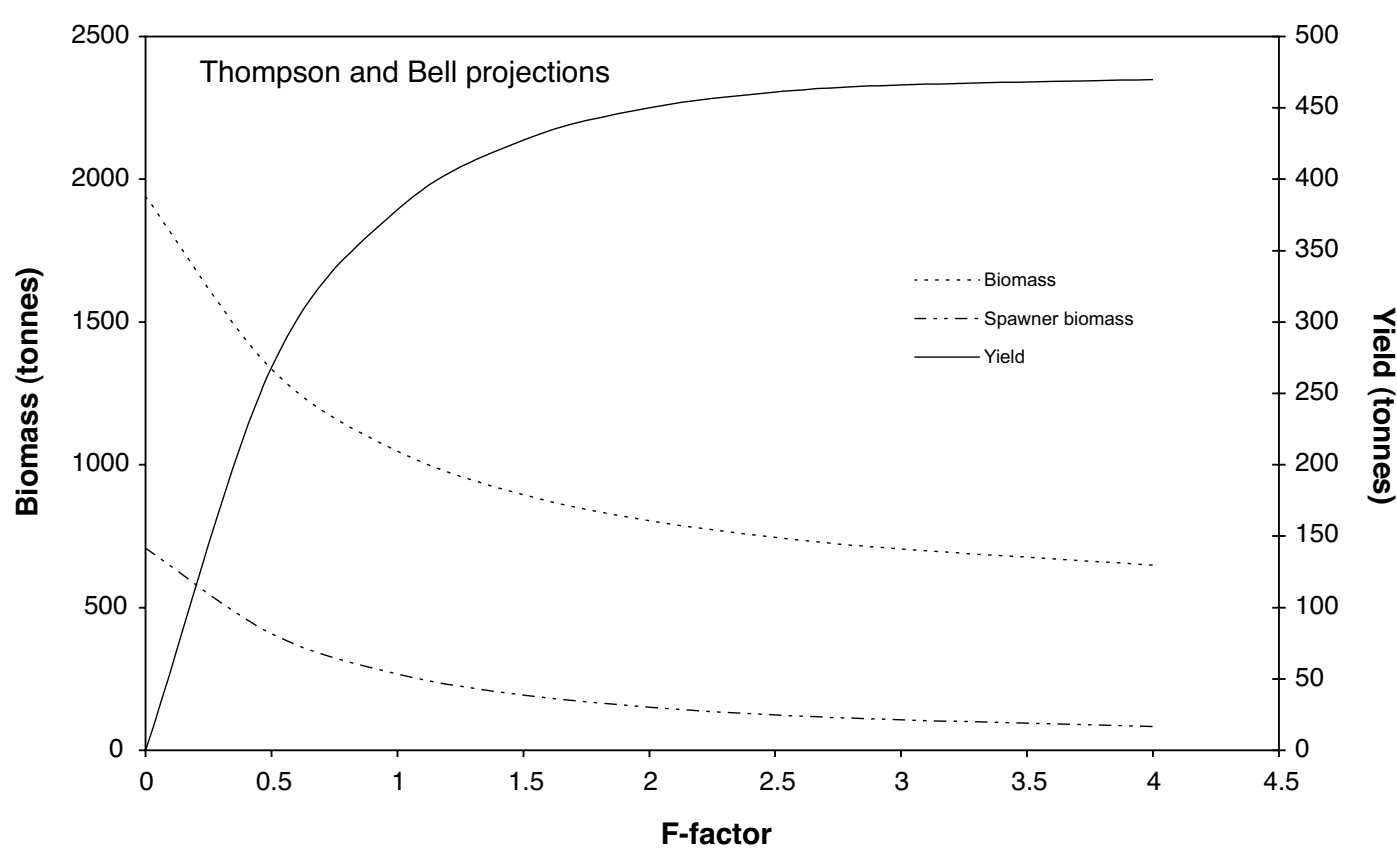

Fig. 8. Thompson and Bell projections of total biomass, spawning biomass and yield (all in tonnes) for a range of fishing strategies $(\mathbf{0}<\mathrm{F}$-factor $<4)$

1988 ( $\mathrm{n}=293$, females only, data from Johnson $1989)$ to $78.7 \pm 8.4 \mathrm{~mm}$ (2003 females, $\mathrm{n}=469)$ and to $68.5 \pm 9.5 \mathrm{~mm}$ (2005 females, $\mathrm{n}=383$ ), although the exact location of the 1988 sample is unknown and may have been a site with particularly large lobsters. Nevertheless, the Al-Wusta region is close to the northern distribution limit of this species in the Arabian Sea, and is therefore presumably a less favourable lobster habitat than Dhofar - hence the smaller mean sizes compared to Dhofar in ou study and the more pronounced declines in size structure.

The estimates of size at sexual maturity of female $P$. homarus from the present study are similar to those made by other researchers throughout its distribution range in the western Indian Ocean (Table 4). The bulk of these studies confirm that maturity is reached at a relatively small CL of between 50 and $70 \mathrm{~mm} \mathrm{CL}$. The highe estimates of $80-85 \mathrm{~mm} \mathrm{CL}$ by Al-Abdulsalaam (1989) and Johnson and Al-Abdusalaam (1991) are as a result of a using allopatric growth of walking legs as an estimator of maturity, rather than eggbearing. Size at maturity, growth rates, fecundity and population size structure of spiny lobsters vary substantially over time and space in relation to their harvesting, fluctuating natural productivity and changing population densities (MacDiarmid and Sainte-Marie 2006). This was also observed for the recent data in Oman, with spatial differences between the Al-Wusta and Dhofar estimates (see Fig. 4). A large reduction of $8.2 \mathrm{~mm}$ was observed when comparing size-at-50\% egg-bearing from the recent Dhofar data $(65.7 \mathrm{~mm} \mathrm{CL})$ with similar 1988 data $(73.8 \mathrm{~mm}$ CL; logistic curve recalculated from Dhofar data sourced from Al-Abdulsalaam 1989). The larger sizes at $50 \%$ egg-bearing in Dhofar extended to the 1994/95 period when it ranged between 69.2-75.9 mm CL at three sites (Mohan 1997). The considerable reduction in size-at-50\% egg-bearing since 1988 is presumably linked to the change in population structure as a result of harvesting.

The von Bertalanffy growth parameters $\mathrm{L}_{\infty}, \mathrm{K}$ and $t_{0}$ estimated in the present study were based on seasonally disjunct data, thus to obtain robust estimates, the combined data on males and females were used with several different estimation models. The growth curve that was selected compares well with those from other studies of $P$. homarus in Somalia and Oman in the late 1980s (see Fig. 9). The growth study from Kenya used captive lobsters
Table 4. Estimates of size-at-50\% egg-bearing of female $P$. homarus from various locations in the wester Indian Ocean

\begin{tabular}{lll}
\hline Country (Region) & $\begin{array}{l}\text { Estimate } \\
\text { CL }(\mathbf{m m})\end{array}$ & Reference \\
\hline Oman (Al-Wusta) & $63.9 \mathrm{~mm}$ & This study \\
Oman (Dhofar) & $65.6 \mathrm{~mm}$ & This study \\
Oman (Dhofar) \# & $73.8 \mathrm{~mm}$ & Al-Abdusalaam 1989 \\
Oman (Dhofar) & $69.2-75.9 \mathrm{~mm}$ & Mohan 1997 \\
Iran (Persian Gulf and Sea of Oman) & $63 \mathrm{~mm}$ & Fatemi 2001 \\
Yemen (East Aden)* & $60-70 \mathrm{~mm}$ & George 1963 \\
Somalia (Puntland) & $58 \mathrm{~mm}$ & Fielding and Mann 1999 \\
South Africa (Eastern coast)* & $>54 \mathrm{~mm}$ & Berry 1971 \\
Kenya & $63.4 \mathrm{~mm}$ & Kulmiye et al. 2006 \\
Sri Lanka & $59.5 \mathrm{~mm}$ & Jayakodi 1989 \\
\hline
\end{tabular}

\# Raw data recalculated using a logistic curve

* Empirical estimates based on egg-bearing proportions per length clas

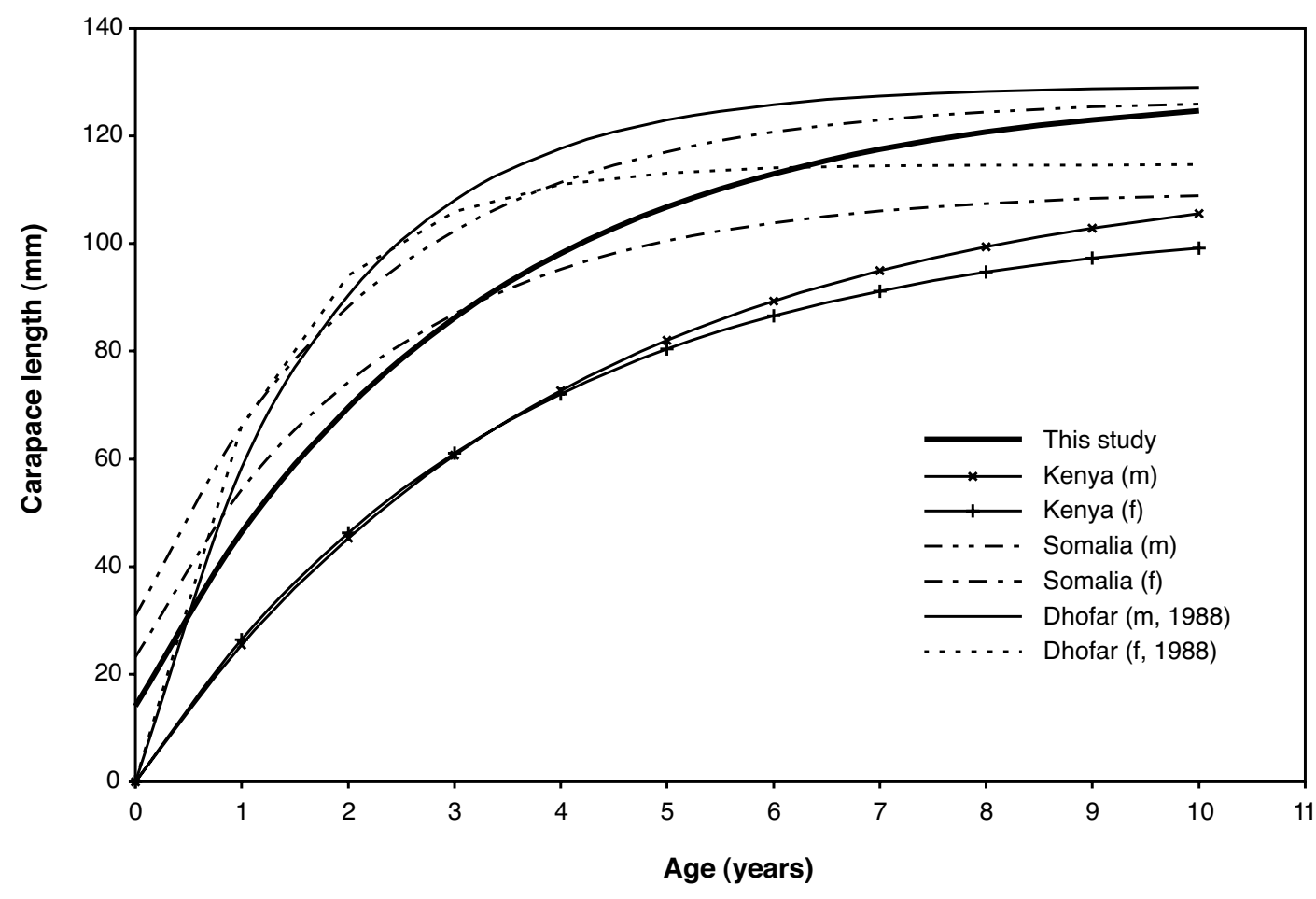

Fig. 9. Von Bertalanffy growth curves calculated for Panulirus homarus in this study, Dhofar in 1988 (Al-Abdusalaan 1989), Somalia in 1998 (Fielding and Mann 1999) and for captive P. homarus homarus in Kenya in 2001-2003 (Kulmiye and Mavuti 2005)

(Kulmiye and Mavuti 2005) and the results are therefore not directly comparable. It appears that $P$. homarus reaches sexual maturity at an age of approximately 2 years and its maximum size at
$8-10$ years after settling as pueruli on the seabed. The natural mortality $(\mathrm{M})$ range obtained in the present study $\left(0.59-0.89 \mathrm{y}^{-1}\right)$ also compares well with estimates from other work, i.e. $0.6 \mathrm{y}^{-1}$ off South 
Africa (Fielding 1997), 0.6-0.85 $\mathrm{y}^{-1}$ off Somalia (Fielding and Mann 1999) and 0.63-1.44 $\mathrm{y}^{-1}$ off Yemen (Sanders and Bouhlel 1984).

The exploitation rate (E) generally gives an indication of the state of exploitation of a stock under the assumption that the optimal value is $\mathrm{E}$ $\approx 0.5$, which in turn assumes that the sustainable yield is optimised when $F \approx M$ (Gulland 1971). In the present study, estimates of $F\left(0.97-1.27 \mathrm{y}^{-1}\right)$ were higher than those of $\mathrm{M}\left(0.59-0.89 \mathrm{y}^{-1}\right)$ and $\mathrm{E}$ thus ranged between $0.52-0.68$, higher than the optimum level. A moderate reduction in effort may therefore be needed to reduce the exploitation rate to around 0.5 . However, the assumption that sustainable yield is optimised when $\mathrm{F}$ is similar to $\mathrm{M}$ has proved to be false in certain situations, and this criterion was used as indicative only.

Considering that initial catches in the fishery were above $2000 \mathrm{t} / \mathrm{yr}$, with some estimates placing it at $>3000 \mathrm{t} / \mathrm{yr}$ in 1985 and 1986 (Al-Barwan et al. 1989), the pristine biomass may have been considerably above $3000 \mathrm{t}$ prior to commercia exploitation. The current biomass estimate of $\sim 1050$ $\mathrm{t}$ at the recent exploitation level places biomass at $<30 \%$ of pristine, and probably closer to $20 \%$. It is important to note that the pre-exploitation population would have consisted of larger individuals (see Fig.8), and that larger females generally carry more eggs and spawn more times per year than smaller individuals (Berry 1971). The reproductive capacity of the present population is thus considerably reduced both in terms of the relative numbers of spawning females at any particular time, as well as smaller clutch sizes, on average.

The shallow-water lobster fisheries in the northwestern Indian Ocean have several factors in common: a high value product and relatively easy access to fishers with small craft and simple fishing gear; declines in reported catches, and possibly depletion of stocks (this study); a lack of speciesspecific biological and fisheries data on which to base assessments and management strategies (Munro 2000; van der Elst et al. 2005); and weak compliance where regulations do exist (this study, Fielding and Mann 1999; Radhakrishnan et al. 2005). The declines in landings and stock depletions together with the heavy reliance on fishing of coastal communities in the northwestern Indian Ocean region clearly creates a fundamental problem, where fisheries managers and governments may struggle to reconcile socioeconomic expectation of fishing communities with sustainable utilization of fish resources.

Acknowledgements - The Agriculture and Fisheries Development Fund of the Sultanate of Oman funded this study through the first phase (2003-2005) of the "Lobster Project". We thank M. Rydha, H. Al-Oufi, A.H. Al-Hosni, and I. Busaidi for their role in securing the funding, and I. Anbory, H. AlWaeli, E. Al-Rasadi, S. Rabeea, M. Al-Hatroshi, R. A-Senaidi, J. Al-Jafari and S. Obeed for technical support and collection of data and biological samples on field trips.

\section{REFERENCES}

Al-Abdulsalaam, T. Z. (1989). Effects of exploitation on life history characteristics of spiny lobster populations (Panulirus homarus) off Oman. Mopulations (Panulirus homarus) off Oman, Oregon, USA.

Alagaraja, K. (1984). Simple methods for estimation of parameters for assessing exploited fish stocks. Indian J. Fish. 31, 177-208.

Al-Barwani, M., Dudley, R.G., Dorr, J.A., Hare, S.R., and Johnson, D.W. (1989). The extent of fishery resources in Oman: Stock assessments and the potential for new resources. In Papers presented by MSFC staff at the International Symposium on Agriculture and Fisheries, Ministry of Agriculture and Fisheries, Sultanate of Oman. MSFC Special Report No. 89-2, Muscat, 10 pp.

Anon. (2001). Fisheries Statistical Year Book (2000) for the Sultanate of Oman. Ministry of Agriculture and Fisheries, Muscat, $238 \mathrm{pp}$.

Anon. (2004). Fisheries Statistics Book (2003) for the Republic of Yemen. General Department for Planning and Statistics. Ministry of Fish Wealth, Sana'a, $224 \mathrm{pp}$.

Anon. (2006). Fisheries Statistics Book (2005) for the Sultanate of Oman. Directorate of General Planning and Investment Promotion. Statistics and Information Department. Ministry of Agriculture and Fisheries, Muscat, $240 \mathrm{pp}$

Berry, P.F. (1971). The biology of the spiny lobster Panulirus homarus (Linnaeus) off the east coast of southern Africa. Investl Rep.Oceanogr. Res. Inst. S. Afr. 28, 1-75.

Berry, P.F. (1974). A revision of the Panulirus homarus group of spiny lobsters (Decapoda, Palinuridae). Crustaceana 27, 31-42.
Beverton, R.J. H., Holt, S.J. (1956). A review of methods for estimating mortality rates in exploite fish populations, with special reference to source of bias in catch sampling. Rapp. P.-V.Reun. CIEM 140, 67-83.

Beverton, R.J. H., Holt, S.J. (1959). A review of the life spans and mortality rates of fish in nature, an their relation to growth and other physiological characteristics. CI-BA Fdn Colloq. Ageing 5, 142-177.

FAO (Food and Agriculture Organization) (2005).http:// faostat.fao.org/faostat/collections?version=ext\& hasbulk $=0 \&$ subset $=$ fisheries

Fatemi, S.M.R. (2001). Lobster fisheries management in the Sea of Oman, In: Proceedings of the First International Conference on Fisheries, Aquaculture and Environment in the NW Indian Ocean. Sultan Qaboos University, Muscat, Sultanate of Oman, pp. 8-14.

Fielding, P.J. (1997). Stock assessment and fisherie management of the Natal rock lobster Panuliru homarus. Oceanographic Research Institute, Durban, South Africa, Unpublished Report 140 pp. 13-19.

Fielding, P.J., and Mann, B.Q. (1999). The Somalia inshore lobster resource - A survey of the lobster fishery of the north-eastern region (Puntland) between Foar and Eyl during November Pugs. So beli Natural Resources Movember 1998. Somall Natural Resonces Management Programme (IUCN-EARO), Project No. 6/SO-
82/95 + 6/SO-83/04, pp. 38 .

George, R.W. (1963). Report to the Government of Aden on the crawfish resources of the Easter Aden Protectorate. Expanded programme of technical assistance, Food and Agriculture Organisation, Rome, Report No. 1696, 1-23.

Groeneveld, J.C., and Melville-Smith, R. (1994). Size at onset of sexual maturity in the South Coast rock lobster, Palinurus gilchristi (Decapoda: Palinuridae) from South Africa. S. Afr. J. Mar. Sci. 14, 219-223.

Gulland, J.A. (1965). Estimation of mortality rates Annex to Arctic working group report ICES C.M.1965/D:3 (mimeo). Reprinted as p. 231 234. In P.H. Cushing (ed.), Key papers on fish populations. Oxford, IRL Press, 1983.

Gulland, J.A. (1971). The fish resources of the ocean. Fishing News (Books) Ltd., West Byfleet, for FAO, 255pp

Hilborn, R., and Walters, C.J. (1992). Quantitative fisheries stock assessment. In: Choice, Dynamic and Uncertainty. Chapman and Hall, New York $570 \mathrm{pp}$.

Holthuis, L. B. (1991). FAO species catalogue. 13. Marine lobsters of the world. An annotated an illustrated catalogue of species of interest to fisheries known to date. FAO Fisheries Synopsis 125 (13), $292 \mathrm{pp}$.

Jayakody, D.S. (1989). Size at onset of sexual maturity and onset of spawning in female Panulirus homarus (Crustacea: Decapoda: Palinuridae) in Sri Lanka. Mar.Ecol.Prog.Ser. 57, 83-87.

Johnson, D.W. (1989). The lobster fishery: potential consequences of sub-optimal management. In Papers presented by MSFC staff at the International Symposium on Agriculture and Fisheries, Ministry of Agriculture and Fisheries, Sultante Mf Oman. MSFC Special Report No. 89-2, Muscat, 17pp. 89-2, Muscat, 17pp.

Johnson, D.W. (1990). Shellfish/Demersal final report. Omani-American Joint Commission. Marine Science and Fisheries Centre, Ministry of Agriculture and Fisheries, Oman. Project no. 272-0101-1-1

Johnson, D.W., and Al-Abdulsalaam, T.Z. (1991) The scalloped spiny lobster (Panulirus homarus) fishery in the Sultanate of Oman. The Lobster Newsletter 4, 1-4.

Jones, R. and Van Zalinge, N.P. (1981). Estimates of mortality rate and population size for shrimp in Kuwait waters. Kuwait Bull. Mar. Sci. 2 273-288.

Kulmiye, A.J., and Mavuti, K.M. (2005). Growth and moulting of captive Panulirus homarus in Kenya, western Indian Ocean. N. Z. J. Mar. Freshwat. Res. 39, 539-549.

Kulmiye, A.J, Mavuti, K.M., and Groeneveld, J.C. (2006). Size at onset of maturity in spiny lobsters Panulirus homarus homarus from Mambrui, Kenya. Afr. J. Mar. Sci. 28, 51-55.

MacDiarmid, A.B., and Sainte-Marie, B. (2006) Reproduction: Chapter 2. In Lobsters: Biology, management, aquaculture and fisheries (BF Phillips ed), Blackwell Scientific Publications, Oxford, 45-77.

Mohan, R. (1997). Size structure and reproductive variation of the spiny lobster Panulirus homarus over a relatively small geographic range along the Dhofar coast in the Sultanate of Oman. Mar. Freshwat. Res. 48, 1085-1091.

Munro, J.L. (2000). Fisheries for spiny lobsters in the thro, J.L. (200). Hesters in the tropical Indo-West Pacific: Chapter 3. In Spiny
Lobsters: Fisheries and Culture (B.F. Phillips and Jobsters: Fittaka eds.), Blackwell Scientific Publications, J. Kittaka eds.),
Oxford, 90-97.

Pauly, D. (1983). Length converted catch curves. A powerful tool for fisheries research in the tropics (Part I). Fishbyte 1, 9-13.

Pauly, D. (1984a). Length converted catch curves. A powerful tool for fisheries research in the tropics (Part II). Fishbyte 2, 17-19. 
Pauly, D. (1984b). Length converted catch curves. A powerful tool for fisheries research in the tropics (Part III: Conclusion). Fishbyte 2: 9-10.

Pauly, D. (1987). A review of the ELEFAN system for analysis of length frequency data in fish and aquatic invertebrates. ICLARM Conf. Proc. 13, 7-34.

Phillips, B.F. and Melville-Smith, R. (2006). Panulirus Species: Chapter 11. In Lobsters: Biology, management, aquaculture and fisheries (BF Phillips ed), Blackwell Scientific Publications, Oxford, 359-384.

Radhakrishnan, E.V., Deshmukh, V.D., Manisseri, M.K., Rajamani, M., Kizhakudan, J.K., and Thangaraja, R. (2005). Status of major lobster fisheries in India. N. Z. J.Mar. Freshwat. Res. 39, 723-732.

Rikhter, V.A. and Evanov, V.N. (1976). On one of the approaches to estimation of natural mortality of fish populations. ICNAF Res. Doc. 76 / VI / 8: $12 \mathrm{pp}$.
Sanders, M.J., and Bouhlel, M. (1984). Stock assessment for the rock lobster (Panulirus homarus) inhabiting the coastal waters of the People's Democratic Republic of Yemen. FAO Report, May 1984, 1-67.

Sparre, P., and Venema, S.C. (1998). Introduction to tropical fish stock assessment. Part 1-manual. FAO Fisheries Technical Paper306/1. Revision 2. FAO, Rome, 407pp.

Van der Elst, R., Everett, B., Jiddawi, N., Mwatha, G., Santana Alfonso, P., and Boulle, D. (2005). Fish, fishers and fisheries of the Western Indian Ocean: their diversity and status. A preliminary assessment. Phil. Trans. R. Soc. A 363, 263-284.

Wetherall, J.A., Polovina, J.J., and Ralston, S. (1987). Estimating growth and mortality in steady state fish stocks from length frequency data. In: Length-based methods in fisheries research. (Eds) D. Pauly and G.R. Morgan. ICLARM, Manila: pp. 53-74.

Zar, J.H. (1984). Biostatistical Analysis. Englewood Cliffs, N. J: Prentice-Hall INC. (Pp. 620). 